\title{
Assessment of Heavy Metal Contamination on Dumpsite in Kuyi Village, Niger State, Nigeria
}

\author{
Joseph Iyakwari ${ }^{1}$, David O. Agbajelola ${ }^{2}$, Timipere. S. Farrow ${ }^{3}$ and Elizabeth J. Eterigho* ${ }^{4}$
}

\begin{abstract}
Soil samples collected from the dumpsite located in Kuyi village, Minna, Niger State were analyzed for copper $(\mathrm{Cu})$, iron $\left(\mathrm{Fe}^{2+}\right)$ and manganese (Mn) using Atomic Absorption Spectrometer. Twenty-one (21) sample points both horizontally and vertically (depth) were studied. The results revealed that Mn had the highest concentration $\left(11.6 \mathrm{mg} / \mathrm{kg}\right.$ ) compared to $\mathrm{Cu}$ and $\mathrm{Fe}^{2+}$. However, it was observed that a minimal reduction in concentration of each metal along the surface of the dumpsite occurred. Interestingly, the concentration of $\mathrm{Fe}$ at all points was relatively high $(5.54 \mathrm{mg} / \mathrm{kg}$, $4.67 \mathrm{mg} / \mathrm{kg}, 3.99 \mathrm{mg} / \mathrm{kg}$ and $3.78 \mathrm{mg} / \mathrm{kg}$ ). Based on the Federal Environmental Protection Agency and Land Disposal Restriction Standard Regulation, this metal could have adverse effect on human health, stream and agricultural activities of villagers around the dumpsite.
\end{abstract}

Keywords - Agricultural activities, Heavy metals, Kuyi village, Municipal Solid Waste

\section{INTRODUCTION}

$\mathrm{M}$ UNICIPAL solid waste (MSW) also referred to as urban solid waste includes mostly house hold waste (domestic waste) with the addition of commercial waste by a metropolis in a given area. They exist in semi-solid or solid form with the exception of industrial hazardous waste [1]. Municipal solid waste includes trash, refuse and garbage consisting of commercial, industrial and domestic waste in both local and urban regions. Decomposed municipal solid waste is waste that has been collected in a dump site over a long period of time and broken down by microorganism. This process supplies nutrient to the soil, thereby reforming it [1]. Major problem faced by the world concerning waste is the disposal, it has become a major challenge because waste that are improperly disposed have serious negative effect on human beings, animal and the environment resulting into climatic change. The environmental effect of solid waste, sewage sludge and polluted sediments are critically prejudiced by their heavy metal content. Assessment of the species of heavy metals aids the determination of the suitability of the

Joseph Iyakwari ${ }^{1}$ was with the Chemical Engineering Department, Federal University of Technology, Minna, Niger State, Nigeria

David O. Agbajelola ${ }^{2}$, is with Chemical Engineering Department, Federal University of Technology, Minna, Niger State, Nigeria

Timipere. S. Farrow ${ }^{3}$ is with the Chemical and Petroleum Engineering, Niger Delta University Wilberforce Island, Bayelsa State, Nigeria

Elizabeth J. Eterigho ${ }^{4}$ is with Chemical Engineering Department, Federal University of Technology, Minna, Niger State, Nigeria. decomposed waste as cover material or compost. The study of different chemical forms of metal ions present in environmental samples is known as "Speciation", and mobility of metals is controlled by their chemical form. Heavy metals could be discussed in various ways, depending on one's point of view. They are group of elements between copper and lead on the periodic Table; having atomic weights ranging 63.546 and 200.590 and specific gravities greater than 4.0 [2]. Most urban and industrial runoff contains a component of trace and heavy metals in the dissolved or particulate form [3].

Living organisms require trace amount of heavy metals but excess of it could result in serious damages to such organism. However, vanadium, iron, nickel, chromium, manganese are above copper on the periodic Table and are all very important due to their effects on living organisms. It is important to note that the accumulation of these metals in the body of mammals over time can cause serious illness [4]. The accumulation of this metal in the body system could result into serious life threatening illnesses and in some cases death. Another way heavy metals could be deposited in the body is through agricultural activities. Crop cultivation, happening around dump site could be contaminated since some of the heavy metals gets leached deep into the soil and crops get their nutrient from soil. When such food is consumed by man, he unintentionally ingests these metals along with the food, poisoning his system and if not checked, over time could result in life threatening issues.

This research assessed a dump site soil as Kuyi village (Figure 1) in Minna, Niger state of Nigeria.

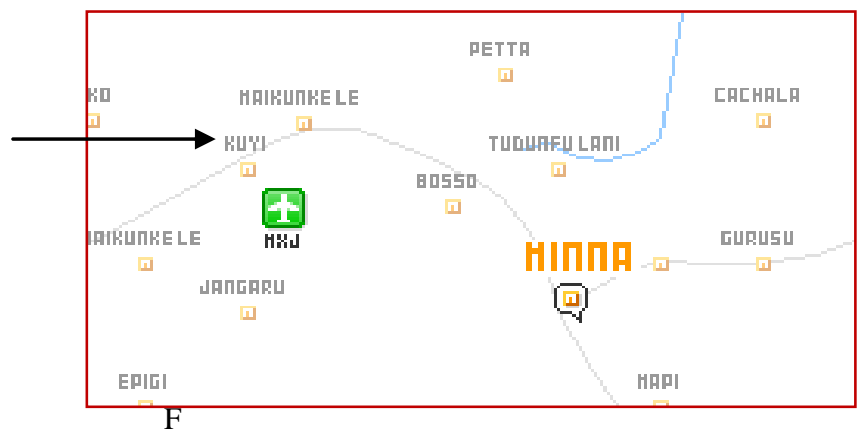

Fig. 1 Map showing Kuyi village in Minna

The metals content analysed were copper $(\mathrm{Cu})$, iron $\left(\mathrm{Fe}^{2+}\right)$ and manganese $(\mathrm{Mn})$ present in the soil at various depths and 
distances for the establishment of safest proximity from the dump site for human settlement and agricultural activity.

\section{EXPERIMENTAL PROCEDURE}

The soil samples were collected from 9 different points at the dump site located in Kuyi village, Minna. A reference point; $30 \mathrm{~m}$ east of the point, at an interval of $10 \mathrm{~m}$, then $40 \mathrm{~m}$ south of same point, at same interval. At each points obtaining 3 samples of soil from each point (top soil sample A, then $1 \mathrm{~m}$ deep sample B, and another $1 \mathrm{~m}$ deep sample C) giving a total sample number of 21. Standard solution of copper, manganese and iron were prepared in harmony with standard methods [5]. The soil samples collected from the dump site were air dried in the laboratory [6]. $5 \mathrm{~g}$ of sieved air-dried soil sample is weighed into a $100 \mathrm{ml}$ plastic bottle. $50 \mathrm{ml}$ of $0.1 \mathrm{~N} \mathrm{HCl}$ was added into the plastic bottles and shake for 30 minutes using multipurpose electronic vibrator. The solution was filtered through whatman No. 42 filter paper into pyrex 100ml capacity volumetric flask. This was transferred into washed sample bottle and kept in dust proof glass chamber for Atomic Absorption Spectrometer (AAS) analysis. Bulk Scientific AAS ; Model: Accusys 210/211VGP was used. The samples were atomized using thermal sources and the absorption of specific wavelengths by atomic source was excited. Radiation from a hollow cathode lamp containing the same element being analyzed was used as cathode. The amount of the same element absorbed by the atomic vapour would be proportional to the concentration of atoms in the soil sample.

\section{RESULT AND DISCUSSION}

The results from the Atomic Absorption Spectrometer showing the amount of each metal in $(\mathrm{mg} / \mathrm{kg})$ are shown in Tables 1 to 3 . The metals analysed were copper $(\mathrm{Cu})$, iron $\left(\mathrm{Fe}^{2+}\right)$ and manganese $(\mathrm{Mn})$. Table 1 shows the results of the studied metals at surface level. The three metals studied were $\mathrm{Cu}, \mathrm{Fe}$ and $\mathrm{Mn}$, at surface level and various depths. These metals were chosen due to low industrial activities in Minna town. Majorly, municipal solid waste mainly domestic waste dominates the dumpsite. It is for this reason that the selected metals were considered, as they are associated with municipal solid waste.

TABLE I

READINGS (MG/KG) AT SuRfACE LEVEL WITH ResPeCT TO DEPTH (SAMPLE A)

\begin{tabular}{cccc} 
Sample & Copper & Iron & Manganese \\
\hline 1 & 0.68 & 5.54 & 11.60 \\
4 & 0.38 & 5.10 & 8.00 \\
9 & 0.17 & 3.78 & 5.40 \\
15 & 0.32 & 4.67 & 7.00 \\
16 & 0.26 & 3.73 & 6.80 \\
20 & 0.18 & 2.27 & 6.30 \\
21 & 0.35 & 3.99 & 7.60 \\
\hline \hline
\end{tabular}

In Figure 2, it was observed that at reference point, Mn was found to have the highest concentration of $11.6 \mathrm{mg} / \mathrm{kg}$ compared to $\mathrm{Cu}$ and $\mathrm{Fe}$. This is the same trend observed at other distances and surface of the dumpsite. However, it was seen that there is a minimal reduction in the concentration of each metals along the surface of the dumpsite. In the case of the $\mathrm{Cu}$, there is no much difference in the amount along the surface from $10 \mathrm{~m}$ to $30 \mathrm{~m}$.

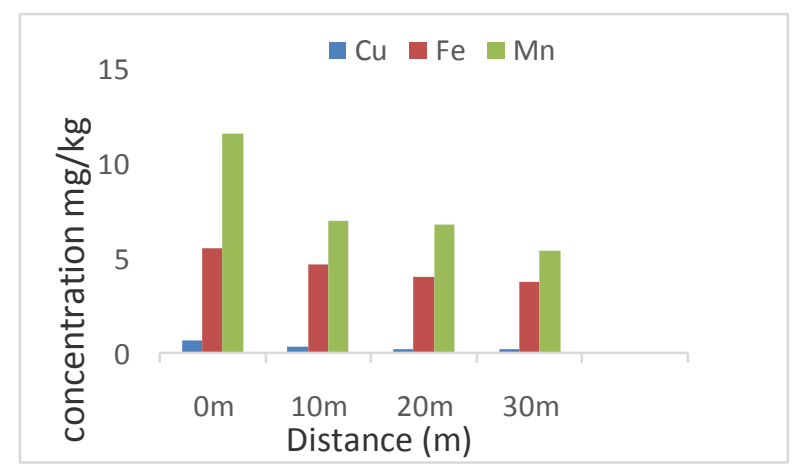

Fig. 2 Concentrations of Heavy Metals along the Surface from Reference Point

Interestingly, the concentrations of $\mathrm{Fe}$ at all the points were relatively constant and high $(5.54 \mathrm{mg} / \mathrm{kg}, \quad 4.67 \mathrm{mg} / \mathrm{kg}$, $3.99 \mathrm{mg} / \mathrm{kg}$ and $3.78 \mathrm{mg} / \mathrm{kg}$ ). This could have adverse effect on human health, streams or agricultural activities of the villagers around the dumpsite [4].

Tables 2 and 3 indicate the amount of copper $(\mathrm{Cu})$, iron $\left(\mathrm{Fe}^{2+}\right)$ and manganese $(\mathrm{Mn})$ in the soil at $1 \mathrm{~m}$ and $2 \mathrm{~m}$ depths respectively.

TABLE II

READINGS (MG/KG) AT 1M DEPTH (SAMPLES B)

\begin{tabular}{cccc} 
Sample & Copper & Iron & Manganese \\
\hline 2 & 0.67 & 3.17 & 5.70 \\
5 & 0.36 & 2.86 & 2.13 \\
10 & 0.24 & 2.43 & 4.50 \\
11 & 0.19 & 3.15 & 4.60 \\
12 & 0.28 & 2.56 & 2.08 \\
18 & 0.20 & 2.37 & 2.02 \\
19 & 0.26 & 2.85 & 1.54 \\
\hline
\end{tabular}

TABLE III READINGS (MG/KG) AT 2M DEPTH (SAMPLES C)

\begin{tabular}{cccc} 
Sample & Copper & Iron & Manganese \\
\hline 3 & 0.31 & 1.89 & 2.95 \\
6 & 0.23 & 1.20 & 2.45 \\
7 & 0.21 & 1.15 & 1.89 \\
8 & 0.26 & 1.13 & 1.03 \\
13 & 0.13 & 1.00 & 1.17 \\
14 & 0.16 & 1.12 & 0.99 \\
17 & 0.27 & 0.62 & 2.51 \\
\hline \hline
\end{tabular}

Concentrations of these metals at the different depths were also evaluated (Figure 3 ). The trend observed was similar to that of the surface soil, although, in lesser amount. 


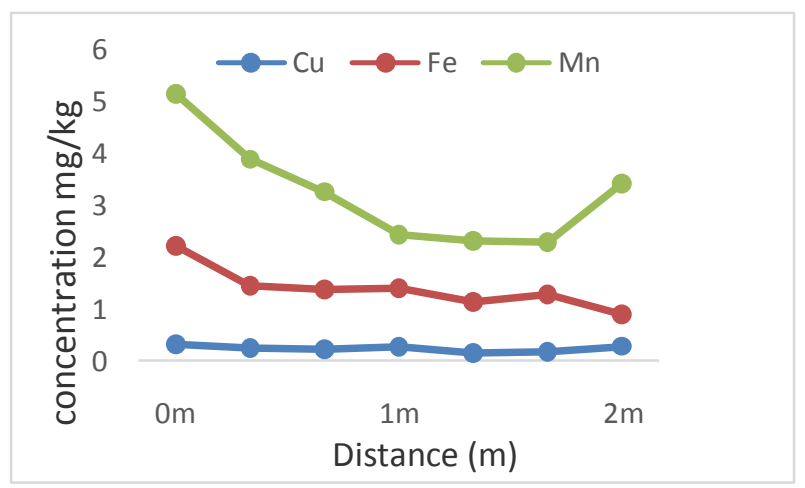

Fig. 3 Concentration of Heavy Metals with Corresponding Depth

The "v" shaped curve obtained suggests; there was no correlation between metal concentration and depth (Figures 3). This could simply be as a result of wind patterns, amount of rainfall or action of settling. However, it could be said that the most concentrated metals are the once found closest to the dumpsite. Another reason for the random deposition of heavy metals in soil is the nature or type of soil. Porous soil that is, soil with relatively good pore space would easily allow the leaching of metals whereas; soil with poor pore space; like silt would not necessarily experience leaching of metals. Therefore, concentration of these metals depends majorly on the point of waste discharge and its proximity to the sample site.

\section{REFERENCES}

[1] USEPA 2012, Municipal solid waste (Assessed 04-11-15) Available at http://www USEPA/ municipal waste/ publication.net

[2] Suciu I., Cosma C., Todica M., Bolboaca S.D. and Jantschi L. (2010) Analysis of Soil Heavy Metal Pollution and Pattern in Central Transylvania International Journal of Molecular Sciences, 9(4): 434453

[3] Defew, L., Mair, J., Guzman, H. (2008). An assessment of metal contamination in Mangrove sediments and leaves from Punta Mala Bay, Pacific Panama. Marine Pollution Bulletin Vol 50, No 5, pp. 547-552. http://dx.doi.org/10.1016/j.marpolbul.2004.11.047

[4] Aderinola O. J., Clarke E. O., Olarinmoye O. M., Kusemiju V. and Anatekhai M. A. (2009). Heavy Metals in Surface Water, Sediments, Fish and Perwinkles of Lagos, Lagoon American-Eurasian J. Agric. \& Environ. Sci., 5(5), pp. 609-617.

[5] Ademoroti, C.M.A. Environment chemistry, Foludex press Ltd Ibadan. pp. $180-200,1996$

[6] Brigden K., Labunska I., Santillo D. and Johnson P. (2008). Chemical Contamination at E-waste Recycling and Disposal Sites in Accra and Koforidua, Ghana Greenpeace Research Laboratories Technical Note, pp.1-23 